\title{
Penelitian
}

\begin{abstract}
ABSTRAK
Pendahuluan: Preeklampsia adalah sindrom kehamilan yang ditandai dengan hipertensi dan proteinuria setelah usia kehamilan 20 minggu, dan merupakan salah satu kegawatdaruratan obstetrik. Dibutuhkan suatu deteksi dini untuk diagnosis preeklampsia sehingga dapat menghindari prognosis yang buruk dari preeklampsia. Kadar asam urat selama kehamilan merupakan salah satu biomarker preeklampsia yang dapat digunakan sebagai penilaian diagnosis preeklampsia. Tujuan penelitian ini adalah untuk mengetahui hubungan kadar asam urat dengan kejadian preeklampsia berat di RSUD Dr. H. Abdul Moeloek Provinsi Lampung.

Metode: Rancangan penelitian ini adalah case control. Populasi kasus adalah ibu hamil dengan preeklampsia dan populasi kontrol adalah ibu hamil tanpa preeklampsia. Sampel kasus sebanyak 31 responden dan kontrol sebanyak 31 responden. Data preeklampsia didapatkan dari pemeriksaan anamnesis dan pemeriksaan fisik sedangkan data kadar asam urat didapatkan dari pemeriksaan laboratorium. Analisis bivariat menggunakan Chi Square.

Hasil: Kelompok kasus (ibu hamil dengan preeklampsia) memiliki kadar asam urat yang lebih tinggi (74,2\%) daripada kelompok kontrol (ibu hamil tanpa preeklampsia) (35,5\%). Berdasarkan analisis bivariat, didapatkan nilai $p=0,0005$ dan OR 5,227 (Cl 95\% = 1,715,5).

Pembahasan: Kegagalan remodeling arteri spiralis yang abnormal pada preeklampsia menyebabkan iskemik seluler plasenta yang akan meningkatkan aktivitas Xantin Oksidase yang dapat meningkatkan produksi asam urat dari jaringan ibu, janin, atau plasenta.

Simpulan: Ibu hamil dengan preeklampsia berisiko lima kali lebih besar mengalami asam urat tinggi.
\end{abstract}

Kata Kunci: asam urat, kehamilan, preeklampsia

\section{ASSOCIATION OF URIC ACID LEVEL WITH SEVERE PREECLAMPSIA IN PREGNANT WOMEN IN RSUD DR. H ABDUL MOELOEK LAMPUNG PROVINCE}

\begin{abstract}
Background: Preeclampsia is a syndrome of pregnancy after 20 weeks gestation and is one of obstetric emergencies. Early detection of preeclampsia is needed to avoid poor prognosis of preeclampsia. Uric acid level during pregnancy is a biomarker of preeclampsia that can be used as a diagnostic assessment of preeclampsia. The purpose of this study
\end{abstract}


is to know the association of uric acid level with severe preeclampsia in pregnant women in RSUD Dr. H. Abdul Moeloek Lampung Province.

Method: The design of this research is case control. Case population were pregnant women with preeclampsia and control population were pregnant women without preeclampsia. This case control study included 31 pregnant women with preeclampsia as case population and 31 women without preeclampsia as control. Diagnosis of preeclampsia obtained by measuring acid levels from laboratory test. Bivariate analysis is using ChiSquare analysis.

Results: The case group (pregnant women with preeclampsia) have higher uric acid levels (74.2\%) than the control group (pregnant women without preeclampsia) (35.5\%). Based on the bivariate analysis, the value of $p=0.0005$ and $\mathrm{OR} 5.227(95 \% \mathrm{Cl}=1.7-15.5)$.

Discussion: The failure of abnormal spiral artery remodeling in preeclampsia causes placental cellular ischemia which will increase the activity of Xanthine Oxidase which can increase uric acid production from maternal, fetal, or placental tissues.

Conclusion: The result of this research is pregnant women with preeclampsia has a five times higher risk to have high level of uric acid.

Keywords: preeclampsia, pregnancy, uric acid

\section{PENDAHULUAN}

Preeklampsia adalah sindrom kehamilan yang memengaruhi banyak sistem organ, yang ditandai dengan hipertensi dan proteinuria setelah usia kehamilan 20 minggu. Angka kejadian preeklampsia diperkirakan mencapai 3$10 \%$ kehamilan di seluruh dunia dan termasuk penyebab utama kematian ibu hamil. ${ }^{[1]}$ Lebih dari $70 \%$ kematian ibu disebabkan oleh perdarahan, infeksi, aborsi yang tidak aman, persalinan terhambat, dan gangguan hipertensi pada kehamilan, termasuk preeklampsia dan eklampsia.[2]

Preeklampsia merupakan salah satu kegawatdaruratan obstetrik yang mengancam jiwa, sehingga perlu penanganan cepat dan tepat untuk mencegah morbiditas dan mortalitas. ${ }^{[3]}$ Secara global, angka kejadian preeklampsia berkisar antara $5-7 \%$ pada kehamilan. Di negara berkembang seperti Indonesia, angkanya cukup tinggi yaitu sekitar $5-10 \%$ dari kehamilan. ${ }^{[4]}$ Brett dkk (2003), menyatakan bahwa preeklampsia adalah sindroma sistemik yang merupakan 3-5\% komplikasi dari seluruh kehamilan dan berkontribusi terhadap tingginya tingkat morbiditas dan mortalitas pada ibu dan janin..$^{[5]}$

Pada wanita hamil dengan preeklampsia dapat terjadi perubahan hemodinamik, penurunan aliran darah ke ginjal, berkurangnya 50\% kecepatan filtrasi glomerulus, terjadi peningkatan kepekaan terhadap zat vasopresor, penurunan renin-angiotensin, dan penurunan kadar prostaglandin E. Hal ini menyebabkan penurunan ekskresi asam urat akibat peningkatan reabsorbsi di tubulus proksimal.[6] Preeklampsia umumnya diawali dengan hiperurisemia yaitu peningkatan kadar asam urat sebelum menimbulkan onset manifestasi klinis pada awal kehamilan. ${ }^{[7]}$ Wanita yang menderita preeklampsia memiliki kecenderungan kadar asam urat, hemoglobin, dan kreatinin yang tinggi serta jumlah trombosit yang rendah, dan risiko seksio sesaria yang lebih tinggi.[8]

Berdasarkan penelitian Bellomo dkk (2011), asam urat menjadi penanda utama preeklampsia, namun kadar asam urat pada trimester pertama menjadi penanda yang buruk untuk preeklampsia dengan sensitifitas $\approx 80 \%$, tetapi spesifitas yang rendah untuk SGA (Small for Gestasional Age).[8] Studi yang dilakukan Tejal dan Astha (2014) menyatakan bahwa pengukuran asam urat serum lebih baik untuk indikator preeklampsia daripada pengukuran tekanan darah pada wanita hamil dengan hipertensi.[9] Berdasarkan penelitian Belloma dkk (2011), wanita hamil yang diduga mengalami hipertensi dalam kehamilan dengan asam urat serum $>309 \mu \mathrm{mol} / \mathrm{L}$ dan kenaikan $>113 \mu \mathrm{mol} / \mathrm{L}$ dari trimester pertama secara akurat dapat memprediksi perkembangan preeklampsia lebih lanjut.[8]

Berdasarkan pusat data dan informasi kesehatan Republik Indonesia (2014), angka kematian ibu hamil akibat hipertensi dalam kurun waktu tahun 2010 sampai 2013 mengalami peningkatan. Angka kematian ibu hamil akibat 
hipertensi pada tahun 2010 berkisar $21,5 \%$ sedangkan pada tahun 2013 sebesar 27,1\%.[10] Insidensi preeklampsia di Indonesia yaitu 3-10\% (Manik dkk., 2017). Kasus kematian ibu hamil di Provinsi Lampung tahun 2015 akibat hipertensi sebesar 35 kasus.[12] Sedangkan angka kejadian preeklampsia di RSUD Dr. H Abdul Moeloek Provinsi Lampung menunjukkan bahwa pada tahun 2013 terdapat 481 kasus dan pada tahun 2014 terdapat 337 kasus. Meskipun terjadi penurunan, namun angka kejadian preeklampsia di RSUD Dr. H Abdul Moeloek Provinsi Lampung masih cukup tinggi, sedangkan insidensi preeklampsia periode 1 Juli 2014 - 30 Juni 2015 menunjukkan $58,4 \%$ mengalami preeklampsia berat dan $41,6 \%$ mengalami preeklampsia ringan. ${ }^{[11]}$

Berdasarkan latar belakang tersebut, peneliti tertarik untuk meneliti hubungan kadar asam urat dengan preeklampsia di RSUD Dr. H Abdul Moeloek Provinsi Lampung.

\section{METODE}

Desain penelitian yang akan digunakan adalah Case Control untuk mengetahui hubungan kadar asam urat dengan kejadian preeklampsia berat pada ibu hamil. Populasi terjangkau yaitu seluruh ibu hamil dengan/tanpa kejadian preeklampsia berat di Rumah Sakit Umum Daerah Dr. H Abdul Moeloek Bandar Lampung pada bulan Oktober November 2018. Terdapat 31 sampel kontrol dan 31 sampel kasus dengan teknik consecutive sampling dengan kriteria inklusi ibu hamil yang didiagnosis preeklampsia berat dan bersedia menjadi responden. Kriteria eksklusi yaitu ibu hamil yang memiliki kadar asam urat tinggi sebelum kehamilan berdasarkan hasil anamnesis responden dengan usia kehamilan di bawah 20 minggu, riwayat penyakit kronik (hipertensi kronik, TBC), penyakit gangguan ginjal, dan diabetes melitus. Kadar asam urat normal yang digunakan dalam penelitian ini berdasarkan Desideri dkk (2014) yaitu 2,4-6 mg/dl,

Variabel bebas penelitian ini adalah asam urat. Variabel terikat adalah preeklampsia. Asam urat merupakan data skala kategorik dengan pembagian normal dan tinggi. Preeklampsia merupakan data skala kategorik dengan pembagian tidak preeklampsia dan preeklampsia.

Metode pengambilan data yaitu data primer, data asam urat dengan pemeriksaan finger prick dan preeklampsia berdasarkan rekam medis sebagai data sekunder. Data diambil setelah mendapatkan Persetujuan Etik Penelitian Kesehatan Fakultas Kedokteran Universitas Lampung No.3356/UN26.18/PP.05.02.00/2018 dan izin penelitian dari pihak RSUD Dr. H Abdul Moeloek Provinsi Lampung. Pengolahan data dengan menggunakan uji chi-square dan dilanjutkan dengan odds ratio.

\section{HASIL PENELITIAN}

Hasil dari penelitian ini yaitu pada kelompok kasus (preeklampsia) terdapat sebanyak $23(72,2 \%)$ ibu hamil dengan kadar asam urat tinggi dan sebanyak 8 $(25,8 \%)$ ibu hamil dengan kadar asam urat normal. Sedangkan pada kelompok kontrol (tanpa preeklampsia) terdapat sebanyak $11(35,5 \%)$ ibu hamil dengan kadar asam urat tinggi dan sebanyak 20 $(64,5 \%)$ ibu hamil dengan kadar asam urat normal dapat dilihat pada tabel 1.

Tabel 1. Karakteristik Responden

Berdasarkan Kadar Asam Urat

\begin{tabular}{ccccc}
\multicolumn{5}{c}{ Kerdasarkan } \\
\hline $\begin{array}{c}\text { Kadar } \\
\text { Asam }\end{array}$ & Kasu & $\%$ & Kontr & $\%$ \\
Urat & $\mathrm{s}$ & & ol & \\
\hline Tinggi & 23 & 74, & 11 & 35, \\
& & 2 & & 5 \\
Norm & 8 & 25, & 20 & 64, \\
al & & 8 & & 5 \\
Total & 31 & 100 & 31 & 100 \\
\hline
\end{tabular}


Tabel 2. Hubungan Kadar Asam Urat dengan Preeklampsia

\begin{tabular}{|c|c|c|c|c|c|c|}
\hline & & \multicolumn{2}{|c|}{ Diagnosis pasien } & \multirow[b]{2}{*}{ Total } & \multirow[b]{2}{*}{$\mathrm{P}$} & \multirow[b]{2}{*}{ OR (Cl 95\%) } \\
\hline & & Preeklampsia & $\begin{array}{c}\text { Tidak } \\
\text { preeklampsia }\end{array}$ & & & \\
\hline & & $\%$ & $\%$ & & & \\
\hline \multirow{3}{*}{$\begin{array}{l}\text { Asam } \\
\text { urat }\end{array}$} & Tinggi & 72,2 & 35,5 & 34 & 0,005 & $5,277(1,7-15,5)$ \\
\hline & Normal & 25,8 & 64,5 & 28 & & \\
\hline & Total & 100 & 100 & 62 & & \\
\hline
\end{tabular}

Pada tabel 2, ibu hamil dengan preeklampsia sebagian besar memiliki kadar asam urat tinggi (74,2\%), sedangkan yang memiliki kadar asam urat normal memiliki angka kejadian preeklampsia yang lebih rendah $(25,8 \%)$. Hasil uji statistik dengan chi-square diperoleh nilai $p$ value $=0,005$ sehingga $p \leq 0,05$ maka $\mathrm{H}_{0}$ ditolak. Dengan demikian dapat disimpulkan bahwa ada hubungan yang signifikan antara kadar asam urat dengan kejadian preeklampsia berat. Nilai Odds Ratio (OR) diperoleh nilai 5,227 (Cl 95\% 1,7-15,5), maka dapat disimpulkan ibu hamil dengan preeklampsia berisiko lima kali lebih besar mengalami asam urat tinggi.

\section{PEMBAHASAN}

Hasil penelitian yang didapat pada penelitian ini adalah pada kelompok kasus (preeklampsia) terdapat sebanyak $23(72,2 \%)$ ibu hamil dengan kadar asam urat tinggi dan sebanyak $8(25,8 \%)$ ibu hamil dengan kadar asam urat normal, sedangkan pada kelompok kontrol (tanpa preeklampsia) terdapat sebanyak $11(35,5 \%)$ ibu hamil dengan kadar asam urat tinggi dan sebanyak 20 (64,5\%) ibu hamil dengan kadar asam urat normal.

Patokan kadar asam urat normal yang digunakan dalam penelitian ini berdasarkan Desideri dkk (2014) yaitu 2,4-6 mg/dl, sehingga pada penelitian ini ibu hamil dengan asam urat normal menggunakan rentang 2,4-6 mg/dl dan ibu hamil dengan kadar asam urat tinggi adalah >6 mg/dl. Dari penelitian ini didapatkan bahwa secara keseluruhan jumlah ibu hamil dengan kadar asam urat yang tinggi lebih banyak dibandingkan dengan ibu hamil dengan kadar asam urat yang normal, yang mana ibu hamil dengan kadar asam urat tinggi sebanyak
34 orang $(54,8 \%)$ ibu hamil sedangkan sisanya 28 orang $(45,2 \%)$ ibu hamil memiliki kadar asam urat yang normal.

Kadar asam urat selama kehamilan ditentukan oleh asupan purin dalam makanan serta produksi metabolik asam urat oleh ibu dan janin, serta ekskresi oleh ginjal dan saluran gastrointestinal. Gangguan pada salah satu atau beberapa faktor tersebut dapat mengubah kadar asam urat serum. Pada kehamilan normal terjadi perubahan sistem hemodinamik berupa hemodilusi karena penambahan volume plasma yang lebih besar sehingga terjadi peningkatan aliran darah ginjal yang meningkatkan klirens ginjal untuk asam urat, ureum, dan kreatinin.[11]

Pengukuran kadar asam urat bertujuan sebagai biomarker preeklampsia pada ibu hamil, terutama pada ibu hamil yang memiliki risiko tinggi hipertensi. Di luar negeri pengukuran asam urat sebagai biomarker preeklampsia sudah banyak dilakukan sebagai deteksi dini preeklampsia. Meskipun demikian, rekomendasi ini belum diadopsi secara luas di Indonesia. Hasil penelitian ini sejalan dengan Diwan dkk (2011) yang menunjukkan ada korelasi positif antara kadar asam urat serum yang tinggi dan tekanan darah diastolik yang tinggi dengan $p<0,02$. (13) Penelitian lain yang relevan adalah yang dilakukan Singh dkk (2018), menyimpulkan bahwa kadar asam urat pada ibu hamil dengan preeklampsia lebih tinggi dibandingkan ibu hamil tanpa preeklampsia $(p<0,05)$ sehingga terdapat hubungan yang bermakna antara kadar asam urat dengan kejadian preeklampsia. ${ }^{[14]} \mathrm{Hal}$ ini sejalan dengan penelitian Zangana dan Hamadamen (2018), disimpulkan bahwa 
terjadi peningkatan kadar asam urat serum pada wanita hamil dengan preeklampsia dan efek yang signifikan pada janin dan morbiditas serta mortalitas perinatal.(15) Namun, jika melihat hasil penelitian oleh Pettit dan Brown (2012), tidak semua penelitian menunjukkan korelasi antara peningkatan kadar asam urat dengan hasil maternal dan neonatal yang merugikan. ${ }^{[16]}$

Preeklampsia disebabkan oleh ketidakseimbangan antara faktor angiogenik dan anti antigenik. Hipotesis sentral menunjukkan hasil preeklampsia dari remodeling arteri spiral yang rusak sehingga mengarah ke iskemik seluler di plasenta, yang pada akhirnya menghasilkan ketidakseimbangan antara faktor anti-angiogenik dan proangiogenik. Ketidakseimbangan faktor anti-angiogenik yang menyebabkan disfungsi endotel yang luas sehingga memengaruhi semua sistem organ ibu dan terhambatnya pertumbuhan janin. ${ }^{[17]}$ Hiperurisemia terjadi pada $16 \%$ wanita dengan hipertensi gestasional tanpa proteinuria dan $75 \%$ wanita dengan preeklampsia yang terdiagnosis secara klinis. ${ }^{[7]}$ Peningkatan asam urat menyebabkan penurunan laju filtrat glomerulus dan hipovolemi. ${ }^{[18]}$ Selain itu, peningkatan asam urat serum bisa disebabkan oleh penyakit hipertensi, kardiovaskuler, penyakit ginjal, disfungsi endotel, dan inflamasi sehingga menyebabkan gangguan pada janin. ${ }^{[19]}$ Peningkatan asam urat sering mendahului manifestasi klinis penyakit, termasuk penurunan laju filtrasi glomerulus. Hipovolemi merupakan perubahan awal preeklampsia, sehingga meningkatkan reabsorpsi asam urat yang dapat meningkatkan konsentrasi asam urat serum, namun peningkatan asam urat mendahului pengurangan volume plasma. ${ }^{[18]}$ Peningkatan produksi asam urat dari jaringan ibu, janin, atau plasenta disebabkan oleh proses kerusakan jaringan yang meningkat (misalnya peningkatan ketersediaan substrat) dan/atau peningkatan aktivitas XO (Xantin Oksidase) juga dapat menjelaskan peningkatan konsentrasi asam urat. Rangsangan spesifik yang bertanggung jawab atas peningkatan aktivitas XO pada wanita preeklampsia tidak jelas. Kemungkinan peran cedera iskemia-reperfusi plasenta sehingga mengurangi kapasitas antioksidan dan stres oksidatif.[7]

Hiperurisemia pada pasien dengan gangguan hipertensi kehamilan merupakan faktor risiko yang kuat untuk beberapa komplikasi ibu dan perinatal.[20] Pada ibu hamil dengan preeklampsia cenderung ditemukan kadar asam urat tinggi dalam darah dan dapat dijadikan sebagai indikator perburukan ibu dan bayi...[21]

Asam urat adalah salah satu tes laboratorium yang paling umum yang dilakukan pada pasien preeklampsia. Kadar asam urat pada preeklampsia telah dieksplorasi secara ekstensif sejak tahun 1917. Diketahui bahwa peningkatan terjadi pada preeklampsia dibandingkan dengan kehamilan normal. Beberapa alasan menjelaskan peningkatan kadar asam urat pada preeklampsia. Pertama, vasokonstriktor seperti angiotensin II dikaitkan dengan penurunan sekresi urat ginjal, penurunan aliran darah ginjal dan penurunan filtrasi glomerulus. Kemudian diikuti dengan penurunan klirens asam urat. Kedua, preeklampsia ditandai dengan invasi trofoblas yang buruk, yang memperburuk hipoksia, spesies oksigen reaktif (ROS), dan stres oksidatif. Hipoksia merangsang produksi asam laktat, yang menghalangi sekresi asam urat. Lebih lanjut, peningkatan retensi asam urat meningkatkan aktivitas simpatis, sehingga menurunkan kerja sistem angiotensin dan memperburuk hipertensi yang ada pada preeklampsia. Asam urat serum meningkat secara signifikan dalam kehamilan hipertensi dibandingkan dengan kelompok tanpa hipertensi serta dapat menentukan tingkat keparahan dalam kehamilan dengan hipertensi. ${ }^{24]}$

Penulis menyadari ada keterbatasan penelitian ini, yaitu tidak diukurnya kadar asam urat rutin sebelum terjadinya kehamilan sehingga tidak dapat menentukan besar pengaruh kadar asam urat terhadap prognosis preeklampsia berat.

\section{SIMPULAN}

Terdapat hubungan kadar asam urat dengan kejadian preeklampsia pada ibu hamil di RSUD Dr. H. Abdul Moeloek Provinsi Lampung, sehingga asam urat 
dapat menjadi penilaian diagnosis preeklampsia.

\section{SARAN}

Berdasarkan kesimpulan yang telah diberikan di atas, maka saran yang dapat dijabarkan oleh peneliti adalah:

- Kadar asam urat terbukti berhubungan dengan kejadian preeklampsia berat sehingga pengukuran kadar asam urat bisa diaplikasikan pada ibu hamil yang berisiko mengalami preeklampsia.

- Perlu adanya penelitian lebih lanjut mengenai seberapa besar cut off atau nilai batas kadar asam urat terhadap prognosis preeklampsia berat.

\section{UCAPAN TERIMAKASIH}

Ucapan terima kasih penulis ucapkan kepada dr. Rodiani, SpOG, dr. Nurul Utami, dan dr. Intanri Kurniati, Sp.PK yang telah membantu dalam proses penelitian ini.

\section{DAFTAR PUSTAKA}

1. Duley L. The Global Impact Of Pre-Eclampsia And Eclampsia. Semin Perinatol. 2009;33(3):1307.

2. WHO, WORLDBANK. Trends in Maternal Mortality: 1990 to 2010. Organization [Internet]. 2012;32(5):1-55. Available from: http://whqlibdoc.who.int/publicati ons/2010/9789241500265_eng.p df

3. Kementrian Kesehatan Republik Indonesia. Rencana operasional promosi kesehatan ibu dan anak. Jakarta: Pusat promosi kesehatan; 2010.

4. Departemen Kesehatan RI. Profil kesehatan Indonesia 2005. Jakarta: Departemen Kesehatan RI 2007; 2007.

5. Young BC, Levine RJ, Karumanchi SA. Pathogenesis of preeclampsia. Annu Pathol Mech Dis. 2010;5:173-92.

6. Sumanti N, Noormartany, Alamsyah M. Kadar Asam Urat Serum sebagai Biomarker Preeklamsi Serum Levels of Uric
Acid as a Biomarker in Preeclampsia. Mkb [Internet]. 2013;45(2):98-104. Available from:

journal.fk.unpad.ac.id/index.php/ mkb/article/download/89/pdf_28

7. Bainbridge SA, Roberts JM. Uric Acid as a Pathogenic Factor in Preeclampsia. Placenta. 2008;29(SUPPL A):67-72.

8. Bellomo G, Venanzi S, Saronio P, Verdura C, Narducci PL. Prognostic Significance of Serum Uric acid in Women With Gestational Hypertension. Hypertension. 2011;58(4):704-8.

9. Tejal P, Astha D. Relationship of Serum Uric Acid Level to Maternal and Perinatal Outcome in Patients with Hypertensive Disorders of Pregnancy. Gujarat Med J. 2014;69(2):1-3.

10. Kementerian Kesehatan RI. Infodatin Pusat Data dan Informasi Kementerian Kesehatan RI [Internet]. Pusat Data dan Informasi Kementrian Kesehatan RI: Penyebab Kematian Ibu. 2014. p. 8. Available from: www.depkes.go.id/resources/do wnload/pusdatin/infodatin/infodati n-ibu.pdf

11. Manik IN, Sari RDP, Wulan AJ. Hubungan Status Preeklampsia dengan Kejadian Perdarahan Postpartum pada Ibu Bersalin di RSUD Dr H Abdul Moeloek Provinsi Lampung Periode 1 Juli 2014 - 30 Juni 2015. Majority. 2017;6:51-7.

12. Dinas Kesehatan Pemerintah Provinsi Lampung. Profil Kesehatan Provinsi Lampung Tahun 2015. 2016. 1-252 p.

13. Diwan J, Shah C, Dixit R, Anand AK. A Comparative Study of Serum Uric Acid Level in Normal Pregnancy, and Pregnancy Induced Hypertension. IJMEDPH. 2011;1(1):39-42.

14. Singh AK, Kumar R, Singh VK, Srivastava S, Sharma A. Serum uric acid levels in pregnancy induced hypertension preeclampsia. Int $\mathrm{J}$ Clin Biochem Res. 2018;5(3):365-8.

15. Zangana JM, Hamadamen Al. 
Serum Uric Acid as a Predictor of Perinatal Outcome in Women with Pre-Eclampsia. Int $\mathrm{J}$ Med Res Heal Sci. 2018;7(3):168-74.

16. Pettit F, Brown MA. The management of pre-eclampsia: What we think we know. Eur J Obstet Gynecol Reprod Biol [Internet]. 2012;160(1):6-12. Available from: http://dx.doi.org/10.1016/j.ejogrb. 2011.09.049

17. Gathiram P, Moodley J. Preeclampsia: its pathogenesis and pathophysiolgy. Cardiovasc J Afr. 2016;27(2):71-8.

18. Gallery E, Hunyor S, Gyory A. Plasma volume cntraction: a significant factor in both pregnancy-assiciated

hypertension (pre-eclampsia) and chronic hypertension in pregnancy. Q J Med. 1979;48:593-602.

19. Khurshid R, Shamsi A, Fayyaz I, Zia M. Maternal Serum Uric Acid Level during Pregnancy: A Biomarker for Preeclampsia. PJMHS. 2016;10(2):413-6.

20. Kondareddy T, Prathap T. Uric acid as an important biomarker in hypertensive disorders in pregnancy. Int J Reprod Contraception, Obstet Gynecol. 2016;5(12):4382-4.

21. Bellomo G. Serum uric acid and pre-eclmpsia: an update. Expert Riviews. 2014;5(3).

22. Toshniwal S, Lamba AR. Serum uric acid as marker of severity of pre-eclampsia. Int J Reprod Contraception, Obstet Gynecol. 2017;6(11):4915-7.

23. Saleh F, Shukar-ud-din S, Soomro N. Serum uric acid as predictor model for pre eclampsia. Dep Obstet Gynaecol Unit II Dow Univ Heal Sci Karachi. 2010;26(3):246-51.

24. Khaliq OP, Konoshita T, Moodley J, Naicker T. The Role of Uric Acid in Preeclampsia : Is Uric Acid a Causative Factor or a Sign of Preeclampsia? Curr Hypertens Rep. 2018;20:80.

25. Niraula A, Lamsal M, Majhi S, Khan SA, Basnet P. Significance of Serum Uric Acid in Pregnancy
Induced Hypertension. J Natl Med Assoc [Internet]. 2017;1-5. Available from: http://dx.doi.org/10.1016/j.jnma.2 017.01 .009 